https://doi.org/10.22364/hssl.28.1.06

\title{
BACKSLIDING OF DEMOCRACY IN CENTRAL AND EASTERN EUROPE: THE REASONS AND POSSIBILITIES FOR SUSPENSION EXAMPLES OF HUNGARY AND SOME OTHER COUNTRIES ${ }^{1}$
}

\author{
Olena Babinova \\ $\mathrm{PhD}$
}

\begin{abstract}
This article is about the problem of democratic backsliding in some of postcommunist central and eastern European (CEE) countries, which have shown very positive achievements in democratic development at the beginning of the transformation processes in the 1990s. The purpose of this article is not only to analyse the transformational processes from democracy to autocracy in former democratic countries, but also to explore the main steps of the authoritarian leaders of these countries towards concentration of power "in one hand" and even "coup d'état". This is done in this article to determine countermeasures that in the future will not allow to turn any democratic country into a country with a hybrid or authoritarian regime. These countermeasures are identified in this article.
\end{abstract}

Keywords: democracy, democratic backsliding, public control, post-communist countries

\section{Introduction}

In the early 1990 s of the $20^{\text {th }}$ century, democracy experienced its heyday. The collapse of the Soviet Union led to the emergence of new states that have chosen the democratic path of their development. Not only the postSoviet countries, but also all other countries of the communist camp showed excellent results on the path to democracy, human rights and other democratic freedoms and values. The emergence of new democracies gave hope for the development and strengthening of democratic norms and principles not only in post-Soviet and post-communist space, but throughout the world. It was a complex transformational process of changes that affected many areas of life of the reformed countries.

1 This article was prepared within the framework of the Central European University CEU/ HESP Research Excellence Fellowship and funded by the Soros Foundation. The author thanks to the Central European University and the George Soros Foundation for possibility to carry out this research. 
The events of the late 1980s - the fall of Berlin Wall, the end of Cold War, and the dissolution of Soviet Union in 1991 - were the basis for democratic transformation in many countries in the world. As a famous fighter for democracy George Soros (1994) noted: "There was a moment of euphoria, in 1989, when people felt liberated from an oppressive regime and that moment could have been used to set into motion the transition to an open society".

It was obvious that countries following the path of democratic development would thereby ensure their effective functioning - they would provide wide participation of citizens in government decisionmaking processes, develop appropriate measures and overcome corruption, thanks to close cooperation of power and citizens, they will provide the development of these countries in many areas, fields and directions. But something went wrong. Some countries of new democracy have failed to create an effective system of public participation and as a result - public control, to overcome corruption and to demonstrate effective and productive results of the development of the country on the whole. To this were added other problems - the gradual (and in some cases sharp) withdrawal of some countries from democracy, its norms and principles. As a result, there was a transition from democratic forms of governance to mixed or even authoritarian. If before, it was transition from authoritarian approaches to democratic, now there is a transition from democracy to autocracy in some countries. In the post-communist space they are Russia, Hungary and some others. As it was noted by András Bozoki and Hegedús Dániel (2018), “even though the number of liberal democracies has increased, more noteworthy is the significant widening of the grey zone between democracies and dictatorships and the rise of new forms of non-democracies. In other words, the number of mixed regimes or, as they are better known, hybrid regimes, has considerably increased".

The main questions in this context are the following:

Why some of post-communist countries, which were showing the great success in formation and development of democracy have changed their priorities in further development? How it was possible to transform the democratic country to authoritarian or country with hybrid regime? Is it possible on the basis of an analysis of the steps and stages of this transformation to define the possible measure to avoid it in the future and in general to block these processes from the side of democratic international society?

This article intends to analyse the process of breakdown of democracy into autocracy in some countries in post-communist space and define the possible measures to make this transformation impossible in the future. 
Thus, the goal of the article is to define the all possible measures, methods, and mechanisms for preventing the transition of democratic countries to the path of authoritarianism.

There are many researches on the topic of transition from autocracy to democracy, but there is some lack of current research on transition from democracy to autocracy, and particularly on how to avoid it, how to help citizens (by concrete mechanisms and instruments) who want to live in democratic society to prevent transformation of their countries from democratic to totalitarian. One of the questions in this context is: Which measures and legal instruments will prevent a democratic country from appearance of totalitarian leader and, as a result, transformation of a country from democratic to hybrid or even authoritarian? Some of these countermeasures, some directions of it will be defined in this article. Many scholars analyse the problem of democratic backsliding in post-communist space (Attila Ágh, 2016; András Bozóki, 2011, 2012, 2017, 2018; Bogaards, Matthijs, 2018; Aron Buzogány, 2017; Licia Cianetti, James Dawson, Seán Hanley, 2018; György Csepeli, 2018; Zoltán Fleck, 2017; David Jancsics, 2017; Bálint Magyar, 2018, 2019 et al.). They have made a significant impact on analysis of the process of democratic backsliding. And now, in research it is important to go further, from description of these processes to proposals on how to stop democratic backsliding by concrete mechanisms and measures, how to change situation, how to have an impact on it both inside (citizens of a country) and outside (international democratic society, as well as relevant organisations). This article is an attempt to achieve it.

Some scholars argue that it is not possible to have any significant impact on these processes in post-communist countries. However, on the basis of an analysis of the main common steps of authoritarian leaders in their coup d'état in former democratic countries, it is totally possible to develop these countermeasures.

\section{Decline of Democracy in Post-Communist Space. Example of Hungary}

Considering the problems of democratic backsliding in some countries in post-communist space many scholars note that the most problematic countries with democracy in post-communist space are Hungary, Russia, and some Asian countries.

Licia Cianetti, James Dawson and Seán Hanley (2018) in their paper "Rethinking "democratic backsliding" in Central and Eastern Europe looking beyond Hungary and Poland" analyse the democratic processes in Central and Eastern Europe on the example of Hungary and Poland. They argue that over the past decade, a scholarly consensus has emerged 
that that democracy in Central and Eastern Europe (CEE) is deteriorating, a trend often subsumed under the label "backsliding". The label "backsliding", which originates as a religious term meaning a failure to maintain piety and Christian faith, has been criticized because of its moralistic and normative overtones. However, this emergent paradigm has focused disproportionately on the two most dramatic cases: Hungary and Poland and on the symptoms - executive aggrandisement and illiberal nationalism - that are most characteristic of the trajectories of those states. The scholars note that not only Hungary and Poland have some problems with democracy, but some other countries of Central and Eastern Europe. However, they define that the most problematic country is Hungary.

Many other scholars argue that the most authoritarian power in Central Europe now is in Hungary. Some scholars even called it "mafia state" (Bálint Magyar, György Csepeli, Zoltán Fleck, David Jancsics, Kim Lane Scheppele et al.). According to A. Bozóki (2018), Victor Orbán, Prime-Minister of Hungary "replaced the constitution with what was called Fundamental Law, which essentially states that the citizens are ready to adjust to a new order, as he named the "System of National Cooperation". In 2011 a coup directed from above took place in Hungary".

The situation in Hungary with democratic backsliding was described by A. Bozóki even in 2011, at the beginning of the full-scale transformation of Hungary from a democratic country into a country with an autocratic, as some researchers call it, or, as other scientists call it, a hybrid regime: "the some problems notwithstanding, Hungary remained until relatively recently (until the eve of 2006), a success story of democratic consolidation. By 2011, however, Hungarian society was forced to realise that the system that had become increasingly freer over the decades had come to a standstill, and it was turning in an autocratic direction". In his article "Occupy the State: The Orbán Regime in Hungary" (2011) he raises the following questions: Is it possible to roll back history? Is it possible to return to an autocratic system as a fully-fledged member of the European Union? What is necessary to do for defence of democracy? What is the role of European institutions if this process?

In another publication "An externally constrained hybrid regime: Hungary in the European Union" András Bozóki and Dániel Hegedűsb define the regime in Hungary as hybrid regime. And they raise a very important problem of the EU role in the process of transformation of Hungary and other countries-members EU from democracy to hybrid regimes and even autocracy:

Due to its hitherto overlooked characteristics, the Orbán regime belongs to a specific class of hybrid regimes. Although currently being made up only by a single item, Hungary, bearing in mind the ongoing 
democratic backsliding in East-Central Europe in general, and Poland in particular, the separation of hybrid regimes evolving within the European Union (EU) as a distinct subtype of hybrid regimes is justifiable both from a theoretical and practical perspective. Consequently, the unique properties of the Hungarian hybrid regime follow from the fact that it is part of the EU, which is made up of democratic member states. Since member states transfer parts of their sovereignty to the EU, the EU is both the loci of "domestic" and "foreign" policy-making; that is, as regime theory suggests, it is both the context in which the Hungarian government operates and an integral part of the Hungarian regime itself. Consequently, the EU functions as a "regime sustaining", a "regime constraining", and, last but not least, as a "regime legitimising" factor for Hungary, which compels one to describe the current political system of Hungary as an "externally constrained hybrid regime" (p. 1174).

It is clear that in accordance with EU values and priorities any countrymember of EU must be a democratic country, and, in the case of some backslidings from democracy, the EU should apply concrete tools and measures in relation to the problematic country. However, now it is not possible to say that these measures exist and are applying. At the same time many scholars note that any hybrid regime is flexible - it can go both in the direction of democracy and in the direction of dictatorship. So, rapid reaction of EU in these cases is necessary condition for stabilisation of the situation and support democracy.

Leonardo Morlino (2012) argues that a key element that runs against the effective existence of hybrid regime, that is, institutional set-ups that are not democracy, nor authoritarianism, nor traditionalism, is the expected low probability of duration. In fact, once some degree of freedom and competition exists and is implemented in various ways, it seems inevitable that the process will continue, even though the direction it will actually take is unknown. It might lead to the establishment of a democracy, but it could also move backwards, with the restoration of the previous authoritarian or other type of regime, or the establishment of a different authoritarian or nondemocratic regime.

As it was noted by Attila Ágh (2014, p. 15), in Hungary the crisis of the democracy has taken place markedly in both aspects of democracy, i.e. in the formal democratic institutions (violating the procedural democracy with rule of law, and the checks and balances system) and in their public performance. Therefore, Hungary may offer itself as a worst-case scenario, even when looking back until 2010, but it is much more so, if the period the Orbán governments has also been taken into account.

According to Bálint Magyar (2016), Hungary is a post-communist mafia state. He defines that the term "post-communist" is descriptive of the mafia 
state, pointing to the circumstances of its formation, the conditions of its germination, that is, to the fact that this is a system that came about though with some delay - in the wake of the one-party dictatorship that went hand-in-hand with a monopoly on state owned property. The author notes that the notion "mafia state" is definitive of the way in which this state functions. He points out that all that had begun in Hungary between 1998 and 2002 - the first time Fidesz had come to power - and has been fully realised since 2010 is best compared with what has happened in most of the countries of the former Soviet Union: Russia under Putin, Azerbaijan, or other Central Asian former member republics of the Soviet Union.

In his other publication B. Magyar (2017) continues to analyse the situation in Hungary and gives a clear definition of a mafia state. He notes the following: "The emerging post-communist criminal states, where the governance bears the features of a criminal organization, can be described as post-communist mafia states. It is nothing less than the privatized form of a parasite state. In this case, the central bodies of the state itself operate in concert as a criminal organization, as the organized upper world". He clearly defined the basic features of a mafiastate and key players of this kind of state. The key players of the mafia state the author defines as: the poligarch - someone who uses legitimate political power to secure illegitimate economic wealth; the oligarch someone who from legitimate economic wealth, builds political power for himself; the stooge - someone who has no real power, neither in politics, nor in the economic sphere, but is a bridge over the gap between the real nature of power and its required legitimacy; and the corruption broker someone who brings the partners of the corrupt transaction together in the role of mediator or expert lawyer.

In the article "The Decline of Democracy in East-Central Europe. Hungary as the Worst-Case Scenario", its author Attila Ágh (2016, p. 279), has given his vision on the reasons for transformation from democracy to autocracy in Hungary. He noted that actually, the young democracy in Hungary before 2010 was a "chaotic democracy," with weakening formal institutions and strengthening informal political-business networks. The weak state was unable to cope with the parallel, complex, and multidimensional processes of systemic change, in which the economic, political, and social changes not only had very different time perspectives, but also confronted each other. In a word, the deep and quick economic transformations of the transition from planned to market economy produced huge social contradictions, with high unemployment and large social exclusions, and the weak democratic state was unable to control this social exclusion in a "responsible" way. People felt that all these changes took place above them and that they had to pay a high price for 
marketization and democratization. Without a participative democracy, the formal institutions were continually weakening, with the result that, by 2010 , democracy was to a great extent emptied.

As it was noted before, when there are some threats to democracy in the modern world, the democratic institutions that were created to support democracy, its values, must intervene and, through special mechanisms, counteract the processes of moving away from democracy, especially in the once democratic countries. Such international institutions as the United Nations, the Council of Europe and others were created in order to promote stability in the world, to develop and strengthen democratic values and human rights. Understandably, they should have the special measures and instrument for this activity. What was the reaction of EU institutions and special preventive measures? Many scholars have noted that the reaction of special organisations was weak and insufficient.

This opinion is shared by B. Magyar (2016, p. 283), who also emphasises the inactivity and even the lack of appropriate measures in European community. He notes that there is a reason to fear that the Hungarian mafia state will not be a unique phenomenon among the ex-communist member states of the European Union. Although a constellation of unfortunate circumstances is needed for its emergence, the temptation is also present elsewhere. In his opinion, the European Community lacks not only the effective tools for expulsion, but even for the disciplining of countries conducting themselves this way.

András Bozóki and Hegedús Dániel (2018) considering the role of Hungary in the European Union emphasise the lack of effective mechanisms for protecting democracy by the EU. The authors claimed that many scholars who analyse the post-2010 relationship of Hungary and the EU, agree that the EU was not capable of standing up effectively to the constitutional engineering process, which has led Hungary in an authoritarian direction. Regarding its function as a systemic constraint, the EU played a Janus-faced role. On the one hand, as expressed in its own discourse of legitimisation, the European Commission lacked the political and legal tools to confront effectively the Hungarian government over the dismantling of liberal democracy and liberal constitutionalism except for initiating infringement proceedings against the country. A. Bozóki and H. Dániel discuss the problem of sliding from democracy to dictatorship in Hungary, its solutions, and the relevant EU policy and steps. They argue that despite the EU's weak opposition to Hungary's transformation from a democratic state to an authoritarian state, the absence of appropriate effective mechanisms, the country's membership in the EU still requires it to be democratic. They noted that even though the EU could not stop the deconstruction of liberal democracy, it did help to slow down and 
prevent the undermining of liberal constitutionalism and the concomitant curbing of human rights and liberties in Hungary. Consequently, it is fair to say that membership in the EU matters: the EU has structurally constrained the hybrid regime. Ultimately, the human rights and liberties of Hungarian citizens are not guaranteed by such constitutional institutions as the Constitutional Court or the Ombudsperson, because these were neutralised during the illiberal constitutional engineering, but by the EU and the European Court of Human Rights of the Council of Europe.

In order to prevent a totalitarian leader from coming to power in a democratic state and, as a result, transforming of a country from a democratic one into a country with a hybrid or authoritarian regime, both internal and external tools must be applied. And now one can say that these instruments, as well as a coherent policy of the entire democratic world community are almost absent. In this case when concrete and effective measures are absent the whole world democratic society can be only as an outside observer. Understandably, it is not the right approach. In the shortest possible time, mechanisms should be developed for both internal and external opposition to the transition of any country from democracy to dictatorship. It will be possible to make on the basis of analysis of the process of the mentioned transformation step by step, to define the common features, common approaches and actions of all authoritarian leader who were trying to change their democratic countries and to seize power and concentrate it in one hand.

\section{Transition from democracy to autocracy in Hungary. How it was}

Just after collapse of the Soviet Union, Hungary was an example of rapid and effective democratization. The priorities of the public policy and governmental activity, the system of public administration was transformed quickly and effectively. As it was described by Kim Lane Scheppele (2016, pp. 15-16), many international observers have been puzzled about Hungary. Hungary was once the star of the post-1989 transition. It was the first in the region to rewrite its constitution to embrace democratic values. It had a steady string of free and fair elections from 1990 through 2010 with regular alternation of governments between left and right. Hungary experienced the largest inward flow of foreign direct investment in post-communist Europe and one of the least chaotic economic transitions. International NGOs put their East-Central European headquarters in Budapest, which was widely regarded as the most stable and sympathetic home for civil society groups in the region. However, less than a decade after Hungary entered the EU, it has become the model "illiberal state," with constitutional checks and balances in near-total collapse, foreign investment in flight, the independence of the judiciary and independent 
media no longer guaranteed, civil society groups under attack, political prosecutions and rigged elections the subject of credible allegations, levels of intolerance against minority groups rising, and a single governing party controlling all public institutions in a non-transparent manner and digging itself in for the long haul.

According to David Jancsics (2017, p. 136), the network structure of grand corruption changed in Hungary after the current Fidesz-KDNP government coalition came in power in 2010. The coalition won two-thirds of the parliamentary seats, which provided them enough power to change the constitution. A small, close-knit group within the governing elite used this unprecedented power to build an organised syndicate. Due to a new, biased Election Law and the official propaganda in 2014, the coalition was re-elected and won local and European elections.

György Csepeli $(2017$, p. 27) describes the coming to power of Viktor Orbán and his party Fidesz in this way: The legal infrastructure forming the bedrock of the mafia state could not have emerged in Hungary without the sweeping success of the single political force at the parliamentary elections of 11 April and 25 April 2010. The first round of the elections drew a turnout of $64 \%$, the second a turnout of $47 \%$, with the Fidesz-KDNP coalition securing 263 seats in parliament. This $68 \%$ turnout corresponds to a majority in legislation of over two-thirds. The opposition was divided and weak in the legislature. The complicated electoral system makes it difficult to gauge the proportion of the voting-age population that the $68 \%$ winning share represents. It is clear that this $68 \%$ of the voting-age population, or over of the citizens that cast a vote, is far more the ratio of those who actually voted for the victorious party, whether one looks at individual constituencies or territorial or national lists. The parliamentary majority was only a majority in the Leninist sense; in reality. It was the expression of a minority's will.

\section{Changes of the Constitution as one but important direction of the coup d'état}

Viktor Orbán and his party Fidesz started their activity from the changes to the Fundamental Law of the country. However, the current Constitution in that time was really democratic. That Constitution was adopted in 1949, and just after collapse of Soviet Union it was significantly amended and improved in the direction of democratic principles and values. But the main task of new Hungarian power was to create legal instruments for their activity.

As it was noted by Zoltán Fleck (2017), the most striking peculiarity of Fidesz's legislative activity is its hyperactivity. On one hand, this means extension of regulatory areas, and on the other, a great volume of quickly 
changing legal norms. Not only do new law have to be brought to govern everything, and any of these be entered into the constitution, but anything can be amended, rewritten, or changed in part or as a whole at any given time. Of course, this takes place with no attention to constitutional or dogmatic principles (p. 74).

As a result of the mentioned above, Hungarian Constitution and other legal acts were changed significantly, and the main logic of it was to create the widest and uncontrolled possibilities for new leader and his party. New Hungarian Constitution which was adopted in 2011 is unique in the context of the responsibilities of the Prime-Minister: they are absent. In Art.15 of the Constitution it is defined that: the Government shall be the general body of executive power, and its responsibilities and competences shall include all matters not expressly delegated by the Fundamental Law or other legislation to the responsibilities and competences of another body. It means that on the basis of this norm, it is possible to expand unlimitedly the power of Prime-Minister.

The new leaders of the country did not stop on these changes. Many amendments were made further to the Constitution. The main results of these legal changes were defined by Imre Vörös (2017) as the following:

- The independence of local governments and accordingly, their right to own property were removed from the fundamental rights, thus local governance, effectively, was abolished.

- The right to social welfare was eliminated.

- Every Hungarian citizen's right to turn to the Constitutional Court (action popularis) was eliminated.

- The three-member Budget Council (with a quorum of two) gained the right to veto the central budget. Taken together with the powers of the President of the Republic, this implies the latter's right to dissolve the parliament in the absence of an approved central budget, even shortly after an election.

- The Constitutional Court's oversight of budgetary and tax laws was abolished only to be "revived" if the government debt was below $50 \%$ of the gross national product. Even in case the above-mentioned "debt brake" is observed, such a development would likely to occur in no sooner than approximately sixty years.

- The Supreme Court was eliminated, which served as an excuse to remove its president from office, even though the Curia was declared to be the Supreme Court's legal successor (p. 43).

Imre Vörös (2017, p. 45) claims that the mentioned legal changes were a constitutional coup and he defines it as a coup d'état carried out with the instruments of constitutional law under the cover of constitutionality, in the form of a series of redrafting and amendments. Ultimately, all of this amounts to a coup against the constitution itself. 
Thus, the first and very significant changes in the direction of concentration of power in one hand in Hungary were changes in the Basic Law, which opened the way to a further backsliding from democracy in the country.

As a result of it, the Commission for Democracy through Law of the Council of Europe, the "Venice Commission," blasted the Hungarian government for treating the constitution as a political tool to keep itself in power. Freedom House, which had labelled Hungary a "consolidated democracy," lowered Hungary in 2015 to the status of a "semi-consolidated democracy," the first time that Freedom House had ever moved a state out of the "consolidated" category. The European Union, Council of Europe, OSCE, United States and others have routinely criticized the Hungarian government (Kim Lane Scheppele, 2016, p. 16).

As can be seen, now international organisations can only ascertain the country's backsliding from democracy and express concern, although, given that this is not happening in one country, but is becoming a certain trend, concrete measures from international institutions in the field of protecting democracy are required in the view of relevant strategies and legislative norms. The main directions of this will be proposed in this article below.

Some scholars, researchers and experts talk about the inconsistency of the policies of international organisations in the field of protecting democracy with modern transformational processes. For instance, B. Magyar (2017, 2019) claims that external constraints are, by nature, passive: they are not active policy-shapers, and are at most the signposts of policies violating democratic values or voluntarist economic actions. The EU, assuming a fundamental community of values, builds on the mechanism of warnings, and thus persuasion. In places where the community of values is lacking, it is unable to prevent the emergence of an autocratic regime. International organisations are easily ensnared in the usual trap of action against the dictatorships, with sanctions dealing a heavy blow to citizens while leaving the political regime unscathed. Moreover, external warnings and sanctions also risk prompting those holding the power to turn even more to unlawful, coercive measures to maintain equilibrium, and are able to mobilize their followers in the name of national self-defence.

According to all above-mentioned one can make a conclusion on the necessity of transformation of the main approaches of all powerful organisations in the field of democracy, to make a shift from simple statement of concern or personal sanctions, which is completely ineffective, to specific measures and concrete actions to prevent the transformation of democratic countries into authoritarian.

As it was noted before, the constitutional coup was only one direction on the way to transition from democracy to autocracy in Hungary. All other directions were transformed as well. It was clearly described by K. L. Scheppele (2016, p. 21): 
"The Orbán government orchestrated a coordinated attack on all of the independent institutions in the country soon after it came into office in 2010. Local governments were neutralized as independent sites of power. Established cultural and educational institutions were battered by accusations of unpatriotic conduct and then defunded, even as new "national" institutes of culture and education were formed. The NGO sector was strangled financially and finally attacked by the public prosecutor and tax office. Churches were used instrumentally to provide ideological cover, but the "official" churches themselves seemed all too willing to go along by trading their support for the regime for material subsidies. Vicious campaigns against the holdouts in each of these categories were conducted by law and law enforcement, by public funding and defunding, and by a public campaign highlighting the disloyalty of those who refused to bend to Orbán's will. Within a few years, there were no major independent bodies of state left standing and the independent civil society organizations outside the state were hanging by a thread."

Further in this article, an analysis of common steps of authoritarian leaders in the direction of concentration of power in their hand on the basis of the concrete experience of Hungary, Russia and Ukraine (in the period of totalitarian leader V.Yanukovych) will be conducted.

Comparative analysis of the main common steps of authoritarian leaders in different former democratic post-communist countries in direction of concentration power in one hand (coup d'état). Possible preventive measures.

- One of the first steps of all authoritarian leaders who came to power in countries with a democratic system of government were changes in the country's Constitution and other important legal acts. By this way they created the legal basis for coup d'état.

\section{$\underline{\text { Russia }}$}

V. Putin did not come to power through elections - he was temporarily handed over the post by the then President of Russia V. Yeltsin. But from the first days of his reign, Putin strengthened the legislative basis of his stay as president of the country. The main constitutional changes that were made: the term of the presidency was extended. However, V. Putin has made many changes to other national legal acts, for instance the election of governors was cancelled, which allowed him to appoint only "his people" in all regions of Russia. At the same time, it is need to note that the main approaches of election of governors and their appointment must be reflected in the constitution of any country. By the author's opinion, any president of any democratic country cannot have possibility to change the system of local government only by personal decision. 
This situation was clearly described by Michael McFaul (2018):

"The single, most consequential choice in Russia's return to autocracy was Yeltsin's decision to select Putin as his successor. Putin had strong, clear preferences for reducing autonomous political activity in Russia; Yeltsin enabled him to do so. At the time of Yeltsin's selection of Putin as his successor in 1999, the Russian political system exhibited some characteristics of an electoral democracy. Early in his tenure as president, Putin utilised the super-presidential constitution adopted in 1993 to make consequential decisions limiting pluralism, political competition, and autonomous sources of power."

In 2024, the second consecutive term of Putin's presidency ends, and under the current constitution of Russia, he cannot run again. Currently, the Russian constitution allows for the presidency of two six-year terms.

In March 2020, the State Duma of Russia approved amendments to the constitution, one of which provides for the "nullification" of Vladimir Putin's presidential term, which he has been ruling in Russia for 20 years. The draft amendments include more than 40 proposals, including strengthening the role of the State Council, reducing Constitutional Court judges and the president's right to dismiss them, and strengthening the requirements for candidates for elected office.

In the event, the cosmonaut and State Duma deputy Valentina Tereshkova voiced the idea to nullify Vladimir Putin's presidential terms after the constitution was approved. Putin then came to the Duma and declared that the idea could be implemented. 20 minutes after Putin ended his speech, the Duma voted in favour and approved it. Thus, it will be incorporated into the Constitution along with other "Putin" amendments: about God, children, the state-building role of the Russian language and the priority of Russian laws over the decisions of international courts.

The Constitutional Court of the Russian Federation on Monday March 16, 2020 passed a law amending the country's basic law that allows President Vladimir Putin to remain in power for another 16 years. The court ruled two days after Putin signed the law.

\section{Hungary}

Viktor Orbán and his party Fidesz started their activity from the changes to the Fundamental Law of the country. However, the current Constitution in that time was really democratic. That Constitution was adopted in 1949 , and in 1989, just after collapse of Soviet Union, it was significantly amended and improved in the direction of democratic principles and values. But the main task of new Hungarian power was to create legal instruments for their activity.

As it was noted by Zoltán Fleck (2017, p. 74), the most striking peculiarity of Fidesz's legislative activity is its hyperactivity. On one hand, this means 
extension of regulatory areas, and on the other, a great volume of quickly changing legal norms. Not only do new laws have to be brought to govern everything, and any of these be entered into the constitution, but anything can be amended, rewritten, or changed in part or as a whole at any given time. Of course, this takes place with no attention to constitutional or dogmatic principles.

As a result of the mentioned above, Hungarian Constitution and other legal act were changed significantly, and the main logic of it was to create the widest and uncontrolled possibilities for new leader and his party. New Hungarian Constitution which was adopted in 2011 is unique in the context of the responsibilities of the Prime-Minister: they are absent. In the art. 15 of the Constitution it is defined that: "the Government shall be the general body of executive power, and its responsibilities and competences shall include all matters not expressly delegated by the Fundamental Law or other legislation to the responsibilities and competences of another body". It means that in the basis of this norm it is possible to expand unlimitedly the power of the Government and the Prime-Minister. As a result, step by step Hungary has made significant backsliding from democracy. This situation was described by András Bozóki even in 2011, at the beginning of the full-scale transformation of Hungary from democratic country into the country with an autocratic, as some researchers call it, or, as other scientists call it, a hybrid regime: "the some problems notwithstanding, Hungary remained until relatively recently (until the eve of 2006), a success story of democratic consolidation. By 2011, however, Hungarian society was forced to realize that the system that had become increasingly freer over the decades had come to a standstill, and it was turning in an autocratic direction".

\section{Ukraine in the period of the presidency of V. Yanukovych}

At the time when Viktor Yanukovych came to power, Ukraine, in accordance with the Constitution, was a parliamentary-presidential republic; the parliament played a decisive role in the country. One of the first steps of Yanukovych as president of the country was the return of the old constitution of 1996, according to which Ukraine was a presidential-parliamentary. This made it possible for him and his criminal group to gain virtually uncontrolled power. By information of Radio Svoboda (2019), in 2017, the Prosecutor General of Ukraine announced a suspicion of the seizure of state power by ex-President Viktor Yanukovych and ex-Minister of Justice from his then team, Alexander Lavrynovych. Office spokesman Yuriy Lutsenko reported on Facebook that there was a "constitutional upheaval" in 2010 when Yanukovych, Lavrynovych and "their accomplices" returned the 1996 Constitution without the necessary Supreme Council (Verkhovna Rada) decision. As a result, the powers of 
the parliament and the government were significantly reduced in favour of the president. Evidence gathered by the Office of Special Investigations into the prosecution was sufficient to declare former President Viktor Yanukovych and former Justice Minister Alexander Lavrynovych suspected of Article 109 (1) of the Criminal Code - the seizure of state power by conspiracy. This is punishable by imprisonment for five to ten years.

\section{Possible solution of this problem}

Taking into account all above-mentioned, the constitution of any democratic country should indicate that any changes to the Constitution can be made not only after a public referendum, but after wide public discussion. In the post-communist space it can be achieved through relevant recommendations and normative documents of a binding nature, for example, by the Council of Europe. It is possible achieve when country is a democratic country, and after a totalitarian leader comes to power in this country, he or she will not be able to significantly change the basic approaches of the public administration system.

\section{- Another important step of all authoritarian leaders was the attempt to make total control over the media.}

In many countries, particularly countries of new democracy, this problem is very topical. Any media has its owner(s), and it is clear that these owners will require execution of their views and ideas. In any case, they will implement a kind of censorship. In many countries there are special services, committees which are responsible for providing licenses to the media. They have the right to dictate some terms to the media from the state, since in most cases they are appointed by the state. It is clear that nondemocratic forces, if they came to power, will have all opportunities to subordinate the media to themselves, to dictate their conditions, otherwise the license will not be obtained.

\section{$\underline{\text { Russia }}$}

From the first days of his presidency, V. Putin was trying to take all media under personal control, and those efforts were successful. Richard Sakwa (2011) claims that Russia's dominant power system has some distinctive characteristics and one of them is the attacks on media freedom.

Now, the media of Russian Federation is an example of Soviet propaganda, where there is no place for journalists' personal point of view or their personal vision. On different channels, different journalists speak the same words, as if one person were writing the text to them all.

As it was noted by Michael McFaul (2018), Putin moved against independent national television, seizing de facto control of two of Russia's largest television companies, NTV and ORT, within months of coming to power. 
As a result, Russian media are totally dependent. And even more - they do not give true information in most cases for their audience and, unfortunately, this audience is not only in Russia, but many people abroad who can speak Russian watch Russian TV channels and, by this mean, it is a strong mechanism of propaganda and relevant impact on very wide audience.

\section{Hungary}

The same activity was made by new political forces in Hungary which received power in 2010. Kim Lane Scheppele (2016) described how it was: "The media were a particular target of the Orbán regime. While Orbán had a substantial media retinue under his sway before returning to power in 2010 , he quickly gained control over the public broadcasting media through a putsch of its most respected journalists. He then brought the private print, digital and broadcast media to heel with a non-independent media council able to issue bankrupting fines against any media outlet that violated vague content standards. Libel actions brought by members of the Orbán inner circle against those who challenged their performance, or raised questions about their private economic dealings, or simply bothered them, helped to chill criticism".

Another famous researcher of the democratization processes in Hungary Bálint Magyar (2016) continues to describe the impact of the party of V. Orbán Fidesz and noted that Fidesz brought the state-owned public media under its control through the immediate means of authority (commissars, direct orders, censorship). It depoliticized (through threats in the form of arbitrarily imposed sanctions and the advertisement tax) the major private televisions (RTL Klub, TV2). It ghettoized any media with a critical voice (official persecutions, scaring away advertisers). Meanwhile, with state assistance (financial support and illegitimate coercion) the political family built its own private media empire.

\section{Possible solution of this problem}

The last point displays all common for authoritarian leaders' directions of taking media under their personal control. Thus, now it is clear that the special countermeasures should be created and implemented to avoid situation when the mentioned processes can take place in democratic country. It is not possible to implement the special measures in authoritarian country, but in democratic - it is fully possible, by special legislation, first of all. And as in previous point, significant role in these processes in post-communist space belongs to special international institutions in the field of democracy and human rights. How it is possible? First of all, it should the special new strategy on functioning of media with new approaches, new forms of cooperation median and authorities on the basis of above-mentioned challenges. It can be in the view of a Charter, and it 
must be the part of national legislation. New unified standards must be developed that will not allow the media to be influenced by the measures listed above - censorship, intimidation, etc. For example, in Ukrainian law on non-governmental organisations defined that all NGOs can create their media, but this point does not work because it is need to have significant financial resources and for one NGO it is not possible. The author sees a solution of this problem in creation of media resources by an association of NGOs. It will help to create more or less independent media, because it will have several holders - representatives of these organisations, and to solve another problem: any media has its holder and in any case the journalists are dependent from this holder. In the case when media is ruled by several holders (NGOs) it will be more independent in any case.

To prevent mass lies in the media space, special preventive mechanisms and appropriate punishment should be developed. It is clear that it is very difficult to control the veracity or falsehood of information in the media. Today, there are not only the necessary mechanisms, but also the corresponding structures. But to create such structures and prescribe mechanisms is a necessity of current situation. And these structures should focus primarily on lies, which are widespread and implemented on a large scale, as an example with Russia.

- In some still democratic countries, where the processes of backsliding from democracy are just beginning, laws are passed that supposedly are aimed at developing democracy, but in fact contain hidden tools that make its development and even their application impossible. In many cases it is directed on reducing of public control. So, another common step of authoritarian leaders is a creation of measures to reduce public control.

A bright example of it is the Ukraine in the period of V. Yanukovych. In 2010 the Resolution of the Cabinet of Ministers of Ukraine "On Ensuring Public Participation in the Formation and Implementation of State Policy" was adopted. The $2^{\text {nd }}$ part of it is the "Typical Regulation on a Public Council under the Ministry, the other central executive body, the Council of Ministers of the Autonomous Republic of Crimea, the regional, Kyiv and Sevastopol city, district, district administrations in the city of Kyiv and Sevastopol". This Regulation defined the main approaches to formation and functioning of public councils in Ukraine. The goals, tasks, and powers of public councils comply with all democratic norms and requirements for the activities of such councils. At first glance, it seems that all democratic norms are respected, which will allow public councils to effectively fulfil their functions. However, it has not happened in Ukraine. Public councils have become a "pocket" for executive bodies where they were functioning, and their possibilities to control governmental activity remained only "on 
paper". The members of the public councils were only persons loyal to all activities of this body and its leadership. Here is an example how they achieved it:

Point 10 of the Regulation dedicated to the membership in the public council and defines that membership in the public council is terminated on the basis of a decision of the public council in the case of:

- a systematic absence of a member of a public council at its meetings without valid reasons (more than twice);

- notification of the head of the of civil society body, unless otherwise provided by its constituent documents, the withdrawal of its representative and the termination of his/her membership in the public council;

- the cancellation of the state registration of civil society body whose representative is elected to the public council;

- the impossibility of a member of a public council to participate in the work of a public council for the state of health, the recognition by a court of law of a member of a public council of incapacitated or limited capacity;

- submission by a member of the public council of the relevant statement.

So, the second and third points are very controversial. Based on the second point, the head of the public institution, non-governmental organization may withdraw its representative from the composition of the public council without explaining the reasons. However, any leader of institution of civil society is strongly depended from the executive power, because the bodies of executive power register all institutions of civil society, and they cannot function without this registration. Thus, the next point gives to executive body possibility to have unlimited impact and mechanism of influence on all members of the public councils - if they will not loyal to activity of this body, the organisation in which he or she works loses registration and, accordingly, will be closed! If the head of a civil society organisation does not want to lose registration, he/she will demand from representatives of their NGO within the structure of public council full loyalty to this body and its leadership. And, if the leader of civil society organisation is a responsible person and does not want to implement all desires of the leaders of executive body, he/she will simply lose registration. Therefore, only those organisations whose leaders are ready in advance to fulfil all requirements of the executive body in which this public council functions, will propose their candidates for work in the public council. They are ready in advance to support any activity of the executive body and its leader, even non-legal activity. If they do not do it, their registration will be cancelled, according to above-mentioned norms in the Regulation. That is why the public councils in Ukraine are existing formally and do not 
have any impact on power authorities. The situation was not changed even in the period of the presidency of the next President P. Poroshenko, and only now new President of Ukraine V. Zelensky has presented new democratic reforms legal package, but the above-mentioned legal norm was not changed till now.

\section{Possible solution of the problem}

In the EU, and especially in the Council of Europe, as organisation with a large number of members, including post-communist non-EU countries, the requirements for the basic democratic norms that are reflected in the legislation, such as the mechanism for the functioning of public councils and their interaction with authorities, and other forms of wide public control should be clear unified.

- The above-mentioned problem has close links with another - absence in many democratic countries of clear mechanisms to recall of elected officials and to remove the president from office.

Clear and precise possibilities for citizens to change the power between elections - to recall the elected officials, to remove the president from office must be reflected in any democratic constitution. No one can be defended from people in politics who want to receive power for personal purpose and use it for solution of personal tasks and personal enrichment. And a very important task of legislation in this context is to make this activity impossible.

\section{Hungary}

In the Hungarian Constitution, the Parliament of Hungary has significant power. At the same time, after election, citizens do not have any impact on these elected persons. Only the President of the country can dissolve Parliament when the Government's mandate ends, Parliament fails to elect the person proposed by the President of the Republic to serve as Prime Minister within forty days of presentation of the first nomination, or Parliament fails to adopt the State Budget for the current year by $31 \mathrm{March}$ (Art. 3, p. 3 of the Constitution). The President of the country, in turn, is elected by parliament (Art. 10). The impeachment procedure shall require a two-thirds majority of the votes of the Members of Parliament. Voting shall be held by secret ballot". So, Hungarian citizens do not have any power to have an impact on these processes. If they are not satisfied with the activities of the President or Parliament, they will have to wait only for new elections.

In Russian Constitution situation is the same - citizens do not have any power and possibilities to recall the elected officials, as well as the president of the country. 


\section{$\underline{\text { Ukraine }}$}

At the same time, now in Ukraine one can see the example of transformation of the country from hybrid regime to real democracy. In a very short period of time some important laws were adopted - on impeachment of the president, on abolishment of the deputies' immunity, the draft of law "on power of people" is discussing in the Parliament.

In general, Ukraine is an example of several transformations of the regimes: from totalitarian to democratic, from democratic to authoritarian or country with hybrid regime (in the period of V. Yanukovych), and again to democratic (with new president V. Zelensky). It is an example of significant impact of a leader of the country on the situation in it. However, the impact of the citizens on the decision-making process in any case should be much stronger than it is.

\section{Possible solution of the problem}

Any democratic country should have much more democratic instruments, but not only the election. The mechanisms of recalling of elected officials should be defined in the constitutions of any democratic country. For instance, in the constitutions of considering countries Hungary and Russia, these possibilities for citizens to have an impact on elected officials are absent, there are no possibilities for citizens to recall the elected officials and remove the president from office. The same situation was in Ukraine before new president of the country. Now, in a very short period, the relevant changes were made - the appropriate laws were adopted. However, it should be the requirements for all democratic countries, (for example from the side of the Council of Europe), but not only the desire of political leaders to make it or not.

- The influence of international organisations in the field of democracy on the processes of deviation from democracy and the transition from democracy to dictatorship does not correspond to current situation. This influence is very weak and ineffective.

It is clear that in accordance with EU values and priorities any countrymember of EU must be democratic country, and, in the case of some backslidings from democracy, the EU should apply concrete tools and measures in relation to the problematic country. However, now it is not possible to say that these measures exist and are applying. At the same time many scholars note that any hybrid regime is flexible - it can go both in the direction of democracy and in the direction of dictatorship. So, rapid reaction of EU in these cases is necessary condition for stabilisation of the situation and support of democracy. 
As it was noted before, when there are some threats to democracy in the modern world, the democratic institutions that were created to support democracy, its values, must intervene and, through special mechanisms, counteract the processes of moving away from democracy, especially in before democratic countries. Such international institutions as the United Nations, the Council of Europe and others were created in order to promote stability in the world, to develop and strengthen democratic values and human rights. Understandably, they should have the special measures and instrument for this activity. What was the reaction of EU institutions and special preventive measures? Many scholars have noted that the reaction of special organisations was weak and insufficient.

As it was defined by János Kornai (2019), unfortunately, the first sign of danger had little effect. Years went by before the full danger to democracy became clear to Hungarian and foreign observers. The reactions of the EU and other international bodies were slow and feeble. Democracy is a fragile and vulnerable politico-governmental system, since its very liberalism makes it grant freedom of expression and assembly also to enemies of democracy. The EU, built on democratic principles, had, and it seems still has, no effective means of halting anti-democratic actions.

Indeed, the transition from democracy to authoritarianism has been observed in some post-communist countries for more than 10 years, and so far, there has been no corresponding reaction from the institutions that were created to defend democracy. Actually, until now, these organisations are not ready to take certain measures to prevent such negative processes, to control them and to correct them. This is because so far, these necessary measures have not been developed. For example, there are a huge number of documents in the field of democracy developed by the Council of Europe and other organisations that operate in the field of democracy, but over the 10 years of the threat to democracy that was observed, the corresponding reaction, as well as the relevant regulatory documents, has not appeared.

\section{Possible solution of this problem}

The activity of all influential international organisations in the field of democracy and human rights should be revised significantly on the basis of current new challenges and troubles in the democratic world. It is clear that all approaches of all international organisations the main activity of which is to support and defend the peace in the world, strong democracy and human rights should be adjusted and updated to meet modern challenges and problems.

The above-mentioned preventive measures can be implemented through relevant recommendations and normative documents of a binding nature, for example, by the Council of Europe. It is possible achieve when 
country is a democratic country, and after a totalitarian leader comes to power in this country, he or she will not be able to significantly change the basic approaches of the public administration system.

Table 1. The main steps of totalitarian leaders and possible preventive measures

\begin{tabular}{|c|c|}
\hline $\begin{array}{c}\text { Steps of authoritarian leaders to } \\
\text { concentrate power in their hands and } \\
\text { some relevant problems }\end{array}$ & Preventive measures \\
\hline $\begin{array}{l}\text { Any totalitarian leader started from } \\
\text { the changes of the Constitution and } \\
\text { other important legal acts }\end{array}$ & $\begin{array}{l}\text { Any changes to the Constitution can be made } \\
\text { not only after a public referendum, but after } \\
\text { wide public hearings. It should be defined in } \\
\text { the Constitutions of all countries-members of } \\
\text { the Council of Europe. }\end{array}$ \\
\hline $\begin{array}{l}\text { Attempts to make total control over } \\
\text { the media, which became the tools of } \\
\text { propaganda and lies }\end{array}$ & $\begin{array}{l}\text { The mechanisms of media independence must } \\
\text { be improved. Significant role in these processes } \\
\text { belongs to special international institutions } \\
\text { in the field of democracy and human rights. } \\
\text { The special international body to fight against } \\
\text { disinformation should be created. }\end{array}$ \\
\hline Attempts to reduce public control & $\begin{array}{l}\text { In the EU, and especially in the Council of } \\
\text { Europe, as organization with a large number } \\
\text { of members, including post-communist } \\
\text { non-EU countries, the requirements for the } \\
\text { basic democratic norms that are reflected } \\
\text { in the legislation, such as the mechanism for } \\
\text { the functioning of public councils and their } \\
\text { interaction with authorities, and other forms of } \\
\text { wide public control should be clear unified. My } \\
\text { proposals: to create Charter on Public Control. }\end{array}$ \\
\hline $\begin{array}{l}\text { Absence in the legislation of many } \\
\text { democratic countries possibilities } \\
\text { for citizens to remove the president } \\
\text { from office and to recall the elected } \\
\text { officials }\end{array}$ & $\begin{array}{l}\text { The mechanisms of recalling of elected } \\
\text { officials should be defined in the constitutions } \\
\text { of any democratic country. It should be } \\
\text { the requirement for any democratic country. }\end{array}$ \\
\hline $\begin{array}{l}\text { The influence of international orga- } \\
\text { nizations in the field of democracy } \\
\text { on the processes of deviation from } \\
\text { democracy and the transition from } \\
\text { democracy to dictatorship does not } \\
\text { correspond to current situation. This } \\
\text { influence is very weak and ineffective. }\end{array}$ & $\begin{array}{l}\text { The activity of all influential international } \\
\text { organisations in the field of democracy and } \\
\text { human rights should be revised significantly } \\
\text { on the basis of current new challenges and } \\
\text { troubles in the democratic world to meet } \\
\text { modern challenges and problems, to have much } \\
\text { stronger impact on democratic process. }\end{array}$ \\
\hline
\end{tabular}

To implement the above-mentioned preventive measures, to suspend the democratic backsliding in general will be possible only by the relevant activity of international organisations in the field of democracy, like Council 
of Europe as it was noted above. Now international organisations can only ascertain the country's backsliding from democracy and express concern, although, given that this is not happening in one country, but is becoming a certain trend, concrete measures from international institutions in the field of protecting democracy are required in the view of relevant strategies and legal norms.

\section{Conclusions}

On the basis of all above-mentioned, today, there is an urgent need to develop an appropriate strategy that would clearly define the problem, its main components, and mechanisms for overcoming it. This article is an attempt to define all problematic directions and all necessary mechanisms and instruments to block the backsliding from democracy to autocracy or dictatorship in post-communist countries.

Many scholars analyse the problem of democratic backsliding, they clearly describe the problem itself. However, today there is a strong necessity to go from describing the problem to concrete countermeasures, which will not allow the authoritarian leaders to transform democratic country in authoritarian or country with hybrid regime in the future. It should be special measures for two kinds of impact - inside (from the side of citizens and their associations) and outside (from the side of international democratic society). And it is possible to make on the basis of analysis of the main common steps of authoritarian leaders in their coup d'état in before democratic countries. It was made in this article. Thus, the main these steps and relevant preventive measures are the following:

- All authoritarian leaders started from the changes to the Constitution. Solution: Constitution can be changed only by national referendum with wide public discussions. In should be defined in the constitution of any democratic country.

- The main instrument for fight against corruption is wide public control, but in many countries, it is not functioning in full measure or even as a whole. All authoritarian leaders were making attempts to reduce the public control.

Solution: Common European norms such as the European Charter on Public Control.

- In many even democratic countries there are no any clear measures to recall the elected officials and remove the president from office.

Solution: These mechanisms should be defined in all constitutions and be supported by special national legislation.

- Another important step of all authoritarian leaders was the attempt to make total control over the media. 
Solution: it should the special new strategy on functioning of media with new approaches, new forms of cooperation between media and authorities on the basis of above-mentioned challenges. The dependence of media and journalists from the authorities and even media holders should be reduced by special clearly defined mechanisms.

- All authoritarian leaders who came to power in democratic countries can change the country from democratic to authoritarian thanks to 1) weak position of special international organisations in the field of democracy, which are obliged to control such processes and to block them; 2) absence of special concrete strategy to prevent democratic backsliding.

Solution: The activity of all influential international organisations in the field of democracy and human rights should be revised significantly on the basis of current new challenges and troubles in the democratic world. It is clear that all approaches of all international organisations the main activity of which is to support and defend the peace in the world, strong democracy and human rights should be adjusted and updated to meet modern challenges and problems.

\section{REFERENCES}

Ágh, A. (2014). Decline of Democracy in East-Central Europe: The Last Decade as the Lost Decade in Democratization. Journal of Comparative Politics, 7(2), pp. 4-33.

Ágh, A. (2016). The Decline of Democracy in East-Central Europe. Hungary as the Worst-Case Scenario. Problems of Post-Communism, 63(5-6), pp. 277-287.

Bogaards, M. (2018). De-democratization in Hungary: diffusely defective democracy. Democratization, 25(8), pp. 1481-1499.

Bozóki, A., Hegedús, D. (2018). An externally constrained hybrid regime: Hungary in the European Union. Democratization, 25(7), pp. 1173-1189.

Bozóki, A. (2011). Occupy the State: The Orbán Regime in Hungary, Journal of Contemporary Central and Eastern Europe, 19(3), December, pp. 649-663.

Bozóki, A. (2012). The Crisis of Democracy in Hungary. Available at: https:/www.boell. de/en/navigation/europe-north-america-andras-bozoki-the-crisis-of-democracy-inhungary-14645.html [Accessed 15.04.2020].

Bozóki, A. (2017). Nationalism and Hegemony: Symbolic Politics and Colonization of Culture in Hungary. In Twenty-five sides of a post-communist mafia state. Ed. B. Magyar, J. Vásárhelyi. Central European University Press in association with Noran Libro. New York, Budapest.

Buzogány, A. (2017). Illiberal democracy in Hungary: authoritarian diffusion or domestic causation? Democratization, 24(7), pp. 1307-1325.

Christiano, T. (2008). The Constitution of Equality: Democratic Authority and Its Limits. Oxford University Press. 
Cianetti, L., Dawson, J., Hanley, S. (2018). Rethinking "democratic backsliding" in Central and Eastern Europe - looking beyond Hungary and Poland. East European Politics, July, pp. 243-256.

Constitution of Hungary. 1949. Available at: https:/lapa.princeton.edu/hosteddocs/ hungary/1949\%20Hungarian\%20constitution.pdf [Accessed 15.04.2020].

Constitution of Hungary. 2011. Available at: https://www.constituteproject.org/ constitution/Hungary_2013.pdf?lang =en [Accessed 15.04.2020].

Constitution of Ukraine. Available at: https:/www.justice.gov/sites/default/files/eoir/ legacy/2013/11/08/constitution_14.pdf [Accessed 15.04.2020].

Constitutional Democracy in Crisis? (2018). Eds.: M. A. Graber, S. Levinson, M. Tushnet. Oxford University Press, New-York.

Csepeli, G. (2017). The ideological patchwork of the Mafia State. In Twenty-five sides of a post-communist mafia state. Ed. Bálint Magyar, Júlia Vásárhelyi. Central European University Press in association with Noran Libro. New York, Budapest.

Developing Organizations and Changing Attitudes: Public Administration in Central and Eastern Europ. (1996). Proceedings from the Fourth Annual Conference held in Tirana, Albania, March 28-30. Ed. Jak Jabes, NISPAcee, p. 54.

Fleck, Z. (2017). Law under the Mafia State. In Twenty-five sides of a post-communist mafia state. Ed. B. Magyar, J. Vásárhelyi. Central European University Press in association with Noran Libro. New York, Budapest.

Jancsics, D. (2017). From Local Cliques to Mafia State: The Evolution of Network Corruption. In Twenty-five sides of a post-communist mafia state. Ed. B. Magyar, J. Vásárhelyi. Central European University Press in association with Noran Libro. New York, Budapest.

Kornai, J. (2019). The System Paradigm Revisited: Clarification and Additions in the Light of Experiences in the Post-Communist Region. In Stubborn Structures. Reconceptualizing Post-Communist Regimes. Ed. B. Magyar. Central European University Press, Budapest, Hungary.

Magyar, B. (2016). Post-Communist Mafia State. The Case of Hungary. Central European University Press in association with Noran Libro Kiadó, Budapest, Hungary.

Magyar, B. (2017). The Post-communist Mafia State as a Form of Criminal State. In Twenty-five sides of a post-communist mafia state. Ed. B. Magyar, J. Vásárhelyi. Central European University Press in association with Noran Libro. New York, Budapest.

Magyar, B. (2019). Towards a Terminology for Post-Communist Regimes. In Stubborn Structures. Reconceptualizing Post-Communist Regimes. Ed. B. Magyar. Central European University Press, Budapest, Hungary.

McFaul, M. (2018), Choosing Autocracy: Actors, Institutions, and Revolution in the Erosion of Russian Democracy. Comparative Politics, 50(3), April, pp. 305-325(21).

Morlino, L. (2012). Changes for Democracy: Actors, Structures, Processes. Oxford University Press.

Rewati, R. T., Surya, P. P. (2009). Constitution: Evolving Concepts and Prerequisite of a Democratic Constitution, 3 NJA Law Journal, 7, pp. 7-38.

Sakwa, R. (2011). Russia' Identity: Between the "Domestic" and the "International". Europe-Asia Studies, 63(6), August, pp. 957-975. 
Scheppele, K. L. (2016). Foreword. In Post-Communist Mafia State. The Case of Hungary. Central European University Press in association with Noran Libro Kiadó, Budapest, Hungary.

Soros, G. (1994). Dangers of Post-Communism. Soros Foundation, New York, USA.

Stubborn Structures. Reconceptualizing Post-Communist Regimes. (2019). Ed. B. Magyar. Central European University Press, Budapest, Hungary.

Twenty-five sides of a post-communist mafia state. (2017). Ed. B. Magyar, J. Vásárhelyi. Central European University Press in association with Noran Libro. New York, Budapest.

Vörös, I. (2017). A "Constitutional" Coup in Hungary between 2010-2014. On Some Aspects of the Exclusive Systemic Exercise Of State Power With Regard To Constitutional Law, International Law, and European Law. In Twenty-five sides of a post-communist mafia state. Ed. B. Magyar, J. Vásárhelyi. Central European University Press in association with Noran Libro. New York, Budapest.

Yanukovych's “constitutional coup”: a new case of the Prosecutor General's Office. (2017). Available at: https://www.radiosvoboda.org/a/28720493.html [Accessed 15.04.2020]. 